Vol 2 No 1 Juli 2021

Jurnal AlphaEuclidEdu

Received:06/04/2021; Resived:09/05/2021; Accepted:08/07/2021

\title{
MODEL PEMBELAJARAN TEAM GAMES TOURNAMENT MATERI BILANGAN BULAT
}

\author{
${ }^{1}$ Azmi Aqil, ${ }^{2}$ Zubaidah R, ${ }^{3}$ Ahmad Yani T \\ Program Studi Pendidikan Matematika FKIP Untan Pontianak \\ Email: Akalaqil113nu@gmail.com
}

\begin{abstract}
This study aims to explain and describe the effectiveness of the Team Games Tournament (TGT) type cooperative learning model conducted in class VII SMPN 1 Sungai Raya. The method used in this research is descriptive-quantitative. The results obtained from this study are TGT type of cooperative learning is effective enough to be applied to the material integer count operations in SMPN 1 Sungai Raya this can be seen fromThe implementation of the teacher in managing cooperative learning type TGT is in the very good category with an average score of 3.73 , the learning activities of students during learning using the type GI cooperative learning are in the active category with a percentage of $89.2 \%$, the response of students to the application of cooperative learning type TGT is in the positive category and the learning outcomes of students have reached ketstrand classical because $81 \%$ of students have reached the KKM.
\end{abstract}

Keyword: TGT, Effectiviness, SMPN 1 Sungai Raya

\section{Pendahuluan}

Matematika merupakan hal yang wajib untuk dipelajari dipelajari (Saputro et al., 2015). Pentingnya mata pelajaran matematika terlihat pada jenjang pendidikan dasar hingga menengah mata pelajaran matematika selalu dijadikan sebagai salah satu pelajaran utama, hal tersebut juga tercantum dalam Peraturan Menteri Pendidikan dan Kebudayaan Nomor 58 Tahun 2014, pada peraturan tersebut dijelaskan bahwa dalam belajar matematika memiliki beberapa tujuan yang harus tercapai yakni: 1) memahami akan konsep matematika, yaitu kemeampuan dalam menjalankan keterkaitan dan hubungan antar konsep menggunakan rumus secara tepat dalam menyelesaikan suatu masalah; 2) menggunakan pola dan data sebagai dugaan sementara sebelum menyelesaikan suatu masalah; 3) menggunakan penalaran pada sifar bilangan dan dapat melakukan manipulasi matematika dengan baik; 4) mengkomunikasikan suatu gagasan dengan jelas dan tepat; 5) memiliki sikap menghargai, rasa ingin tahu dan minal dalam belajar kegunaan dan manfaat matematika baik di sekolah maupun diluar sekolah seperti dikehidupan sehari-hari, sejalan dengan hal tersebut Ruseffendi (2006: 103); (Tuzahrah et al., 2008); (Yani \& Ningsih, 2016) mengungkapkan bahwa dalam belajar matematika kemampuan menyelesaikan masalah amat sangat penting.

Peneliti mencari informasi dengan cara wawancara kepada guru dikelas VII tahun ajaran 2017/2018 di SMPN 1 Sungai Raya, diperoleh informasi bahwa salah satu materi yang masih sebagian besar peserta didik yang memperoleh nilai dibawah ketuntasan minimal adalah materi operasi hitung bilangan bulat, hal ini dapat dilihat pada tabel 1.1 berikut: 
Vol 2 No 1 Juli 2021

Jurnal AlphaEuclidEdu

Received:06/04/2021; Resived:09/05/2021; Accepted:08/07/2021

Tabel 1.1: Persentase Ketuntasan Hasil Belajar Peserta Didik Materi Operasi Hitung Bilangan Bulat

\begin{tabular}{cccccc}
\hline \multirow{2}{*}{ No. } & \multirow{2}{*}{ Kelas } & \multicolumn{2}{c}{ Jumlah Peserta didik } & \multicolumn{2}{c}{ Persentase (\%) } \\
\cline { 3 - 6 } & & Tuntas & Tidak Tuntas & Tuntas & Tidak Tuntas \\
\hline $\mathbf{1}$ & VIIA & 5 & 22 & $18,5 \%$ & $81,5 \%$ \\
\hline $\mathbf{2}$ & VIIB & 8 & 20 & $28,6 \%$ & $71,4 \%$ \\
\hline $\mathbf{3}$ & VIIC & 5 & 23 & $17,9 \%$ & $82,1 \%$ \\
\hline & & Rata-rata & & $21,7 \%$ & $78,3 \%$ \\
\hline
\end{tabular}

Dari wawancara juga diperoleh informasi bahwa salah satu penyebab rendahnya nilai peserta didik dikarenakan peserta didika kesulitan dalam memahami perintah soal, juga gairah yang ditunjukan oleh peserta didik dalam mengikuti proses pembelajaran yag berlangsung masih rendah. Selain itu, proses pembelajaran yang pasif dan kurang meliatkan peserta didik secara interaktif dapat menurunkan gairah belajar dan menghambat kemampuan belajar matematika peserta didik, sehingga diperlukan model pembelajaran yang sesuai dengan kondisi yang dialami leh peserta didik. Salah satu model pemebelajaran yang diyakini oleh peneliti sesuai untuk diterapkan dengan kondisi peserta didik di SMPN 1 Sungai Raya adalah model pembelajaran Team Games Tournament (TGT).

Menurut Slavin (dalam Huda, 2015: 197); (Latmawati et al., 2017); (Fitriawan et al., 2013); (Sarwono et al., 2017), TGT merupakan model pembelajaran yang berpusat pada peserta didik dan kerja sama anggota antar kelompok, model ini juga bersifat permainan sehingga lebih menyenangkan dan dapat menaikan gairah belajar peserta didik. Pembelajaran TGT akan membuat antar kelompok peserta didik untuk menemukan pengalaman atau informasi, membuat dan mendiskusikan suatu masalah, pengambilan kesimpulan hingga akhirnya pemecahan suatu masalah dalam suatu kompetisi yang menyenangkan.

\section{Metode Penelitian}

Metode penelitian yang akan digunakan oleh peneliti dalam penelitian ini adalah metode dekriptif - kuantitatif. Adapun yang menjadi subjek dalam penelitian yaitu peserta didik pada salah satu kelas VII di SMPN 1 Sungai Raya. Pemilihan subjek penelitian berdasarkan hasil diskusi dan pertimbangan yang dilakukan oleh peneliti dengan guru mata pelajaran matematika dikelas VII di SMPN 1 Sungai Raya. Prosedur penelitian yang akan dilakukan pada penelitian ini terdiri dari tiga tahapan yaitu: tahap persiapan, tahap pelaksanaan dan tahap akhir.

\section{Tahap Persiapan}

Adapun langkah yang dilakukan dalam tahap persiapan adalah :1) Membuat perangkat pembelajaran; 2) membuat dan menyusun instrumen penelitian; 3) melakukan validasi perangkat dan instrumen pembelajaran; 4) Melakukan uji coba soal tes; 5) 
Vol 2 No 1 Juli 2021

Jurnal AlphaEuclidEdu

Received:06/04/2021; Resived:09/05/2021; Accepted:08/07/2021

Menganalisa hasil ujicoba; 6) melakukan perbaikan soal tes, perangkat pembelajaran dan instrumen penelitian berdasarkan hasil ujicoba yan telah dilakukan; 7) Mengajukan surat ijin kepada pihak terkait untuk melakukan penelitian.

\section{Tahap Pelaksanaan}

Langkah - langkah kegiatan yang dilakukan oleh peneliti pada tahap pelaksanaan adalah: 1) menentukan jadwa pelaksanaan penelitian; 2) Melaksanakan pembelajaran dengan TGT pada subjek penelitian berdasarkan RPP yang telah dibuat; 3) Memberikan peserta didik soal tes untuk mengukur kemampuan peserta didik dan menentukan hasil belajarnya; 4) Memberikan perserta didik angker respon pembelajaran TGT unutk mengetahui dan menentukan bagaimana respon peserta didik dengan model pembelajaran TGT.

\section{Tahap Akhir}

Langkah - langkah yang kegaiatan yang dilakukan oleh peneliti pada tahap akhir adalah menyusun laporan dengan baik.

\section{Hasil dan Pembahasan}

\section{Hasil Penelitian}

Hasil Observasi Keterlaksanaan Guru Dalam Mengelola Pembelajaran

Keterlaksaan guru dalam mengelola pembelajaran dikelas via google meet dan wa diamati oleh observer selama proses kegiatan belajar mengajar menggunakan model pembelajaran TGT berlangsung, obeserver dalam penelitian adalah guru mata pelajaran matematika. Hasil dari pengamtan dapat dilihat pada tabel 1.2 berikut:

Tabel 1.2 : Rekapitulasi Data Hasil Pengamatan KGMP

\begin{tabular}{lccc}
\hline \multicolumn{1}{c}{ Aspek yang Diamati } & \multicolumn{2}{c}{ Skor Pertemuan } \\
\cline { 3 - 4 } & I & II \\
\hline Kegiatan Pendahuluan & 13 & 16 \\
\hline Kegiatan Inti & 29 & 30 \\
\hline Kegiatan Penutup & Jumlah Skor & 12 & 12 \\
\hline \multicolumn{2}{c}{ Rata-rata } & 54 & 58 \\
\hline & & 3,6 & 3,86 \\
\hline
\end{tabular}

Dari Tabel 1. 2, terlihat beberapa aspek, dimana tiap aspek mempunyai skor maksimal empat dan skor minimal nol, dari tabel 1. 2 juga terlihat bahwa skor rata rata KGMP pada pertemuan I sebesar 3, 6 dan di pertemuan II sebesar 3, 86. Sehingga apabila diambil rata - rata KGMP di dua pertemuan tersebut dapat dihitung dengan cara: $\frac{R K G_{1}+R K G_{2}}{2}=\frac{3,6+3,86}{2}=3,73$. Sehingga dapat dismpulakan bahwa KGMP menggunakan model pembelajaran TGT tergolong sangat baik.

\section{Hasil Observasi Aktivitas Belajar Peserta Didik}


Vol 2 No 1 Juli 2021

Jurnal AlphaEuclidEdu

Received:06/04/2021; Resived:09/05/2021; Accepted:08/07/2021

Pada penelitian ini ada empat kategori yang menjadi penilaian dalam pengatan aktivitas belajar peserta didik yaitu: visual, oral, listening, writing. Hasil pengamatan aktivitas belajar peserta didik dapat dilihat pada tabel 1.3 berikut:

Tabel 1.3: Rekapitulasi Data Aktivitas Peserta Didik

\begin{tabular}{cccc}
\hline No & Kategori Aktivitas & Rata-rata & Kategori \\
\hline $\mathbf{1}$ & Visual Activities & $100 \%$ & Sangat Aktif \\
\hline $\mathbf{2}$ & Oral Activities & $62,4 \%$ & Aktif \\
\hline $\mathbf{3}$ & Listening activities & $94,6 \%$ & Sangat Aktif \\
\hline $\mathbf{4}$ & Writing Activities & $100 \%$ & Sangat Aktif \\
\hline & Rata-rata Total & $89,2 \%$ & Sangat Aktif \\
\hline
\end{tabular}

Berdasarkan pengematan aktivitas belajar peserta didik selama dua pertemuan menggunakan model pembelajaran TGT materi operasi hitung bilangan bulat diperoleh rata-rata aktivitas belajar yang dilakukan oleh peserta didik sebesar $89,2 \%$ atau berada pada kategori sangat aktif.

\section{Hasil Angket Respon Peserta Didik}

Data angkegt respon peserta didik diberikan ketika peserta didik telah selesai melakukan kegiatan proses belajar mengajar menggunakan model pembelajaran TGT. Hasil dari pengumpulan angket respon peserta didik da[at dilihat pada tabel 1.4 berikut:

Tabel 1.4: Klasifikasi Respon Peserta Didik

\begin{tabular}{cc}
\hline Kategori & Jumlah Peserta Didik \\
\hline Sangat Positif & 7 \\
\hline Positif & 19 \\
\hline Netral & 0 \\
\hline Negatif & 0 \\
\hline Sangat Negatif & 0 \\
\hline
\end{tabular}

\section{Hasil Tes Belajar Peserta Didik}

Persentase hasil tes belajar peserta didik kelas VII SMPN 1 Sungai Raya dapat dilihat pada gambar diagram 1.1 berikut: 
Vol 2 No 1 Juli 2021

Jurnal AlphaEuclidEdu

Received:06/04/2021; Resived:09/05/2021; Accepted:08/07/2021

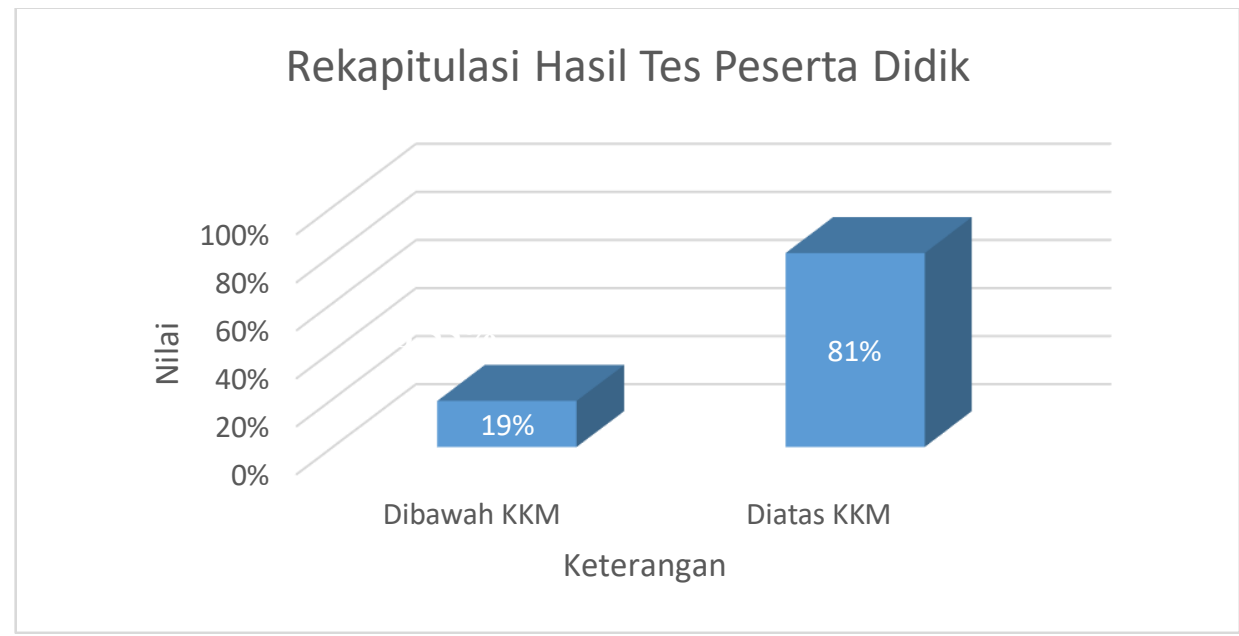

Diagram 1.1: Persentase Hasil Belajar Peserta Didik

Dari gambar diagram 1.1 terlihat bahwa persentase belajar peserta didik $81 \%$ peserta didika diatas kriteria ketuntasan minimal , maka dapat disimpulkan ketuntas hasil belajar secara klasikal telah terpenuhi.

\section{Pembahasan}

\section{Keterlaksanaan Guru Dalam Mengelola Pembelajaran}

Keterlaksanaan guru dalam mengelola pembelajaran menggunakan model pembelajaran TGT materi operasi hitung bilangan bulat diamati oleh seorang observer selama dua pertemuan, prsoes pembelajaran menggunakan applikasi Google Meet dan Whats App (WA).

Dari beberapa aspek yang diamati, KGMP menggunakan model pembelajaran TGT barada pada kategori sangat baik dengan mengikuti langkah - langkah pelaksanaan model pembelajaran TGT dilakukan dimulai dari tahap Class Presentation, Team, Games, Tournament, dan Class Recognition, yang berarti peneliti telah melaksanakan kegiatan proses pembelajaran yang sesuai dengan rencana proses pembelajaran yang telah dibuat sebelumnya dengan baik meskipun kurang maksimal karena proses pembelajaran dilakukan secra daring atau online.

Berikut kegiatan KGMP model pembelajaran TGT materi operasi hitung bilangan bulat untuk tiap aspek. Pada kegiatan pendahuluan pertemuan I guru mengalami kesulitan dalam memberikan penyampaian tujuan tentang mempelajari matematika karena baru pertama kali melakukan proses pembelajaran secara daring menggunakan Google Meet sehingga masih kaku dan agak canggung dan memperoleh skor 3, kemudian pada pertemuan kedua mengalami peningkatan skor menjadi 4 karena sudah tidak mengalami kesulitan lagi,selanjutnya pada kegiatan memberikan motivasi kepada peserta didik dalam pertemuan I memperoleh skor 3 kemudian di pertemuan II mengalami peningkatan mendapatkan skor 4.peningkatan di pertemuan II dikarenakan menurut observer motivasi yang diberikan peneliti masih belum tepat di pertemuan I dan sudah diperbaiki di pertemuan II.

Pada kegiatan inti juga terjadi perubahan, yaitu pada aspek memberikan apresiasi kepada hasil tugas kelompok peserta didik, sebelumnya pada pertemuan I memperoleh skor 3 dan mengalami peningkatan pada pertemuan II sehingga memperoleh skor 4 . Peningkatan ini dikarenakan peneliti lupa dalam memberikan pujian dan apresisasi 
Vol 2 No 1 Juli 2021

Jurnal AlphaEuclidEdu

Received:06/04/2021; Resived:09/05/2021; Accepted:08/07/2021

kepada kelompok yang telah melakukan presentasi. Pada kegiatan penutup keterlaksanaan guru dalam mengelola pembelajaran tidak terjadi perubahan yang berarti pada pertemuan I dan pada pertemuan II.

Aktivitas Belajar Peserta Didik

Aktivitas belajar yang dilakukan oleh peserta didik diamati oleh peneliti dan observer selama proses pembelajaran menggunakan model pembelajaran TGT berlangsung, mulai dari awal hingga akhir pembelajaran selama dua pertemuan. Observer aktivitas belajar peserta didik selama mengikuti pembelajaran dilakukan oleh guru mata pelajaran amtematika SMPN 1 Sungai Raya.

Ada beberapa kategori yang menjadi fokus dalam pengamatan aktivitas peserta didik diantaranya adalah: visual, oral, listening, writing. Berdasarkan tabel 1.3 diperoleh informasi bahwa persentase aktivitas tertinggi diperoleh pada kategori writing activities dan visual activities yaitu sebesar $100 \%$, dan persentase aktivitas terendah pada kategori oral activities. Kemudian pada kategori visual activities peserta didik memperoleh persentase sebesar 94,6\%.

Pada kegiatan visual activities peserta didik berada pada kategori sangat aktif, hal ini dikarenakan peserta didik membaca LKPD yang telah diberikan dan mencari pada sumber belajar lainnya untuk memperoleh informasi yang dibutuhkan yang anntinya akan digunakan untuk menyelesaikan permasalahan yang diberikan.

Pada kegiatan oral activities, peserta didik berada pada kategori aktif dalam kategori ini aktivitas paling sedikit yang dilakukan oleh peserta didik selam proses pembelajaran berlangsung adalah mengajukan pertanyaan, baikitu bertanya pada guru maupun pada teman. Sejak awal pembelajaran berlangsung hingga akhir pembelajaran memang masih sedikit peserta didik yang mau bertanya baik kepada guru maupun teman baik di grup chat saat menggunakan Wa maupun disaat menggunakan aplikasi Google Meet.

Pada kegiatan listening aktivities tergolong pada kategori aktif, hal ini dikarena pada saat melakukan presentasi kelompok, video yang dibuat oleh masing-masing kelompok sudah bagus dan sangat jelas artinyapeserta didik mendengarkan dengan baik apa yang guru instruksikan.

Pada kategori writting activities tergolong pada kategori sangat aktif, hal ini dikarenakan sebagian besar peserta didik menyelesaikan permasalahan yang telah diberikan menuliskan jawaban benar dengan baik dan jelas.

\section{Respon Peserta Didik}

Data mengenai respon peserta didik diperoleh dengan menggunakan angket respon yang diberikan setelah peserta didik diberikan perlakukan pengajaran menggunakan model pembelajaran TGT, adapun jumlah peserta didik yang diminta untuk mengisi angket respon tersebut berjumlah 26 peserta didik dikelas VII SMPN 1 Sungai Raya.

Dari hasil perhitungan angket respon peserta didik yang telah dibagikan kepada seluruh peserta didik diperoleh informasi bahwa 7 peserta didik memberi respon sangat positif dan 19 peserta didik memberikan repon positif. Dari informasi tersebut dapat ditarik kesimpulan rata - rata peserta didik memberikan respon yang positif terhadap pembelajaran menggunakan model pembelajran TGT.

Ada tiga aspek yang difokuskan dalam melihat respon peserta didik yaitu: 1) kegiatan pembelajaran, seperti materi, suasana, cara guru mengajar; 2) pembelajaran menggunakan model pembelajaran TGT, mengenai kegiatan diskusi dan kerja sama 
Vol 2 No 1 Juli 2021

Jurnal AlphaEuclidEdu

Received:06/04/2021; Resived:09/05/2021; Accepted:08/07/2021

antar kelompok, persentasi, kompetisi; 3) perangakat pembelajaran, seperti bahasa yang digunakan, tampilan, dan kemudahan dalam memahami materi menggunakan LKPD.

Berdasarkan angket respon yang telah dibagikan kepada peserta didik mengenai pembelajaran menggunakan model pembelajaran TGT, sebanyak 21 peserta didik tidak mengalami kesulitan dalam belajar secara kelompok dan berdiskusi antar kelompok, pada indikator games sebanyak 23 peeserta didik merasa senang dan antusias dalam melakukan kegiatan games dalam proses pembelajaran, unutk indikator presentasi hasil diskusi dalam proses pembelajaran model pembelajran TGT, 23 peserta didik merasa senang dalam melakukan diskusi dan persentasi bersama kelompoknya selama proses pembelajaran berlangsung.

\section{Hasil Belajar Peserta Didik}

Hasil belajar peserta didik diperoleh dari nilai soal tes yang diberikan peneliti setalah laksanakannya pembelajaran mengunakan model pembelajaran TGT materi bilangan bulat, soal tes yang diberikan kepada peserta didik terdiri dari 4 soal uraian singkat dan 1 soal cerita. Terdapat 26 peserta didik yang mengikuti tes ini, dan 21 peserta didik mendapatkan nilai diatas kriteria ketuntasan minimal. Berikut hasil soal tes yang telah dikerjakan oleh peserta didik untuk tiap butir soal.

Untuk soal nomor 1a, 1b, 1c, dan 1d memuat perintah melakukan operasi penjumlahan dan pengurangan bilangan. Total skor yang diperoleh peserta didik untuk soal nomor 1a, 1b, 1c, 1d masing masing adalah 69, 67, 69, 66 dari skor maksimal 78. Berdasarkan hal tersebut menunjukan bahwa sebagian besar peserta didik yang telah diberikan pembelajaran dengan model pembelajaran TGT mempunyai kemampuan untuk menyelsaikan masalah, namun masih saja ditemukan peserta didik yang masih keliru atau mungkin dalam memberikan tanda negatif pada kesimpulan jawaban.

Untuk soal nomor 2 yang merupakan soal. Total rata - rata skor yang diperoleh adalah 66 hal ini menunjukan masih ditemukan peserta didik yang belum memahami apa yang ditanyakan dalam soal ?, apa yang diketahui dalam soal?, dari soal cerita yang diberikan.

\section{Kesimpulan dan Saran Kesimpulan}

Berdasarkan hasil penelitian dan pembahasan yang twlah dipaparkan oleh peneliti sebelumnya maka dapat ditarik suatu kesimpulan yaitu bahwa model pembelajaran TGT pada materi operasi hitungan bilangan bulat cukup efektif di SMPN 1 Sungai Raya selama masa pandemi COVID - 19 ini.

Dari kesimpulan umum dapat ditarik sub kesimpulan dari masalah yang ada, adapun sub kesimpulan dari masalah tersebut adalah: 1) KGMP menggunak model pembelajaran TGT berada pada kategori sangat baik; 2) aktivitas belajar para peserta didik berada pada kategori aktif; 3) respon yang ditunjukan oleh para peserta didik selam proses pembelajran menggunakan model pembelajaran TGT berlangsung berada pada kategori positif; 4) hasil belajar peserta didik telah mencapai KKM karena $81 \%$ peserta didika telah mencapai KKM secar klasikal.

\section{Saran}

Berdasarkan temuan msalah yang peneliti alami selam proses kegiatan penelitian peneliti menyarankan beberapa hal yaitu: 1) untuk peneliti selanjutnya sebelum melakukan penelitian lebih baik melakukan pendekatan kepada peserta didik dikelas 
Vol 2 No 1 Juli 2021

Jurnal AlphaEuclidEdu

Received:06/04/2021; Resived:09/05/2021; Accepted:08/07/2021

yang akan dilakukan penelitian terlebih dahulu agar proses pembelajaran lebih terasa natural dan tidak terasa asing bagi peserta didik; 2) peneliti sebaiknya mempersiapkan manajemen waktu yang matang terlebih dimas pandemi saat ini agar kegiatan penelitian dapat berjalan dan terlaksan dengan baik diwaktu yang tepat; 3) peneliti sebaiknya melakukan diskusi terlebih dahulu dengan observer dan guru mata pelajaran tentang kegiatan yang akan dilakukan saat penelitian agar komunikasi saat penelitian dapat berjalan dengan baik; 4) selalu pastikan jaringan internet memadai atau berjalan dengan stabil dikarenan proses penelitian ini dilakukan selama pandemi.

\section{Referensi}

Fitriawan, D., Kusmayana, T. A., \& Iswahyudi, G. (2013). Ekperimental Model Pembelajaran Kooperatif Tipe Two Stay Two Stray Dengan Metode Problem Solving Pada Pokok Bahasan Persamaan Garis Lurus Ditinjau Dari Kategori Multiple Intelligences Peserta Didik Kelas VIII Smp Negeri Di kabupaten Karanganyar. c, 113-122.

Huda, M. 2015. Model - Model Pengajaran dan Pembelajaran. Yogyakarta: Pustaka Belajar.

Kemendikbud. 2014. Peraturan Menteri Pendidikan dan Kebudayaan RI Nomor 58 Tahun 2014 Kurikulum 2013 Sekolah Menengah Pertama / Madrasah Tsanawiyah. Jakarta; Kemendikbud.

Latmawati, S. R., Zubaidah, \& Bistari. (2017). Pengaruh Model Pembelajaran Kooperatif Tipe Gi. 8(2), 265-280.

Ruseffendi, E.T. 2006. Pengantar Kepada Membantu Guru Mengembangkan Kompetensinya Dalam Pengajaran Matematika Untuk Meningkatkan CBSA. Bandung; Tarsito

Saputro, M., Yadi, A., \& Dona, F. (2015). Faktor-Faktor yang Mempengaruhi Prestasi Belajar (Studi Korelasi Pada Mahasiswa Pendidikan Matematika IKIP PGRI Pontianak). Jurnal Pendidikan Informatika Dan Sains, 4(2), 233246.

Sarwono, E., Yusmin, E., \& Suratman, D. (2017). Pengaruh Model Pembelajaran Kooperatif STAD.

Slavin, R. E. 2005. Cooperative Learning: Teori, Riset dan Praktik. Terjemahan Narulita Yusron. Bandung: Nusa Media.

Tuzahrah, F., Zubaidah, \& Ijuddin, R. (2008). Analisis Kesulitan Belajar Siswa Dalam Menyelesaikan Soal Bilangan Berpangkat. Jurnal Pembelajaran Khatulistiwa, 1, 1-12.

Yani, A., \& Ningsih, K. (2016). Implementasi Model Pembelajaran Kooperatif Tipe STAD Dalam Mata Kuliah Statistik Dasar Pada Program Studi Pendidikan Matematika. Journal Pendidikan Matematika Dan IPA, 1(3), 31-39. https://doi.org/10.26675/jabe.v1i3.6029. 